\title{
Recent Changes and Variation in Precipitation over Asia-Pacific Region in relation to Long-Term Temperature and MSLP
}

\author{
Gargi Akhoury, ${ }^{1}$ Kirti Avishek, ${ }^{2}$ and Moushumi Hazra ${ }^{3}$ \\ ${ }^{1}$ Department of Physics, BIT, Mesra, Ranchi, India \\ ${ }^{2}$ Department of Civil and Environmental Engineering, BIT, Mesra, Ranchi 835215, India \\ ${ }^{3}$ Faculty of Environment, St. Xavier's College, Ranchi 834001, India \\ Correspondence should be addressed to Gargi Akhoury; gargiakhoury@bitmesra.ac.in
}

Received 9 June 2016; Revised 12 August 2016; Accepted 25 August 2016

Academic Editor: Reza Modarres

Copyright (C) 2016 Gargi Akhoury et al. This is an open access article distributed under the Creative Commons Attribution License, which permits unrestricted use, distribution, and reproduction in any medium, provided the original work is properly cited.

\begin{abstract}
The years 2014 and 2015 turned out to be quite catastrophic for the Asia-Pacific region which took a major toll on the socioeconomic stature of all the entities of the region. The agricultural sector which is one of the most contributing factors to the economy of the region has been highly sensitive to the global climatic changes. Hence this endeavor shall greatly help in an efficient prediction of monsoon cycles, thus enabling the hapless farmers to be better informed and avoid major losses of any kind. The paper focuses on the climatology of air temperature and MSLP with the variation pattern in precipitation over the Asia-Pacific region. The NCEP-NCAR reanalysis data is used for air temperature and MSLP along with high-resolution precipitation dataset for Asia-Pacific monsoon region obtained from GPCP. The temperature datasets are analyzed up to the level $500 \mathrm{hPa}$. Monte Carlo method of correlation and Bootstrapping method of confidence interval are used to analyze the relation of GPCP with MSLP and temperature at all defined levels. So, in this paper authors attempt to assess the nature and relationship of temperature and MSLP to precipitation over the Asia-Pacific region with the recent 10 -year changes which are quantified in detail.
\end{abstract}

\section{Introduction}

It is well thought out that the Asia-Pacific region is the home to approximately $60 \%$ of the world's population with diverse culture, economy, and ecology. This is the region of developing nations where the rapid growth in economies has increased the human prosperity but has exposed the flora and fauna to major exacerbation from our ecosystem. Also, much of this region is dependent upon the annual monsoon, the failure, or limitation of rainfall leads to risks which affect all the entities. The variability which is associated particularly with the El Nino events contributes to cyclic droughts and extreme sea levels in the southwest pacific. Hence, the region is exposed to major crest and trough in climatic conditions.

According to Weihong and Zhu [1], the summer monsoon in this region is defined as follows: when the cool dry southeast trades of the Indian and Pacific Oceans cross the equator and become warm moist wind system, rains/rain spells are produced. A different key description specified by Wang et al. [2] over the Asia-Pacific region is the characterization of the Asian monsoon by the low-level southerlies over Asia and the North Western Pacific. They examined the intrinsic relationship of the summer tropospheric temperature between Asia and the North Pacific. The study focuses on the variation of the Asian tropospheric temperature in relation to Pacific temperature. Choi et al. [3] cover the 143 weather stations in Asia-Pacific Network countries to compile the changes in spatial and temporal patterns in extreme events of temperature and precipitation for the period 1955-2007. The results indicated that there have been seasonally and diurnally asymmetric changes in extreme temperature events relative to recent increases in temperature. With the help of ERA-40 data and numerical simulations, Zhao et al. [4] examined the teleconnection over the extra tropical Asian-Pacific region and its relationship with the Asian monsoon rainfall and the climatological characteristics of tropical cyclones over the western North Pacific. They analyzed the impacts of the Tibetan Plateau heating and Pacific sea surface temperature on the teleconnection.

An observational study was performed by Weihong and Zhu [1], for the different summer monsoon components 
over East Asia and South Asia. In recent years, the Asian monsoon system, prevailing from the Indian subcontinent, the Indochina Peninsula, Mainland China, the South China Sea, and the northwestern Pacific during the late boreal spring to summer, has steadily received more attentions. The three-dimensional structure of precipitation in the monsoon regions of Asia-Pacific was investigated by Li et al. [5]. The data used in this study was the tropical rainfall measurement mission (TRMM) and the three regions covered were the East Asian monsoon region, the Indian monsoon region, and the northwest Pacific monsoon region. Based on the global annotations Goswami [6] reflects on the combination of large-scale spatial and temporal structure and regional propagation characteristics of Asian summer monsoon. Apart from this, a comparative study was done between East Asian monsoon and Indian monsoon by Ka-Ming and Li [7]. With the help of NCEP-NCAR reanalysis data, Singh and Ranade [8] disclose the interannual variability of the Indian summer monsoon and western North Pacific summer monsoon in their temporal-spatial structures, relationships to El Nino, and teleconnections with midlatitude circulations.

Numerous statistical methods were in use to study the pattern of precipitation and its linkage with temperature and mean sea level pressure. Maragatham [9] studied the least squares method to analyze the pattern of the rainfall and it was found that it gives the most accurate results. The intensity of extreme precipitation events increases exponentially with temperature and this theory is based on the principle that the atmospheric moisture holding capacity increases according to the Clausius-Clapeyron equation and on the expectation that precipitation formation should follow accordingly, Berg et al. [10]. The daily precipitation data was used by Yao et al. [11], to study the summer precipitation events and their changes over Asia during 1978-2002. The entire tropicalsubtropical Asian region was covered to see the changes in precipitation amount and precipitation days for total, extreme, heavy, and light-moderate precipitations. The surface air temperature from ERA-40 and the Global Precipitation Climatology Project (GPCP) version 2 for precipitation were taken into consideration to analyze the variability on the global basis for 1979-2002, Trenberth and Shea [12]. The results were then compared with the NCAR Community Atmospheric Model version 3 (CAM3) and Community Climate System Model version 3 (CCSM3). Another method known as the Principal Component Analysis was used by Benzi et al. [13] to analyze the surface precipitation and temperature in Sardinia region.

Let us try to review both the facets of approach towards this study; one aspect tries to study the relation between temperature and precipitation whereas the other aspect endeavors to link the relation between mean sea level pressure, MSLP, and precipitation. Ansell et al. [14] studied various areas in southern Australia and linked the decadal variability in winter rainfall with regional mean sea level pressure and sea surface temperature. With the help of cross-spectral, empirical orthogonal function (EOF) and correlation techniques it was shown that there is a statistically significant inverse relationship between MSLP and rainfall. Lavers et al. [15] used the monthly concurrent correlation to link the spatiotemporal variability in gridded European precipitation and large-scale mean sea level pressure (MSLP) for the period (1957-2002). It was seen that the European precipitation is controlled by physically interpretable climate patterns that change in extent and position from month to month. The result shows that the MSLP-precipitation correlation patterns move and shrink in spring, reaching a minimum in summer, and expand in autumn.

The authors in this paper attempt to map out the variation in precipitation together with temperature and MSLP over the Asia-Pacific region. The temperature, MSLP, and precipitation data period is taken from 1979 to 2013 . The temperature data were examined at each level up to $500 \mathrm{hPa}$, which is a middle tropospheric level. Though an assortment of analysis has been done, showing a relationship of MSLP and precipitation at different regions across the globe but still many more analyses are yet to be done to analyze the relationship through the various lens available to be able to come to a final conclusion about the major parameter which affects the data. The paper tries to present a comprehensive study of the relationship between MSLP and precipitation over Asia-Pacific region. Besides this, the authors strive to explore the recent ten-year change in temperature, MSLP, and precipitation. The results and studies carried out in this work will be helpful to develop a platform for how the monsoon pattern is changing in Indian Subcontinent. Also, it will be easy to compare changes in the monsoon of Indian subcontinent with the rest of the Asia-Pacific region and it would be really of great importance to review how the other regions are impacting the Indian Subcontinent.

\section{Materials and Methods}

The precipitation dataset is obtained from the Global Precipitation Climatology Project which is a monthly precipitation dataset from 1979 to the present. It consists of monthly means of precipitation derived from satellite and gauge measurements with grid resolution $2.5^{\circ} * 2.5^{\circ}$. The full description of GPCP is given by Adler et al. [16].

The temperature dataset is taken from NOAA NCEPNCAR CDAS-1 and covers the period from 1979 to 2013. This is a gridded dataset having the following: Longitude $X$ (degree_east) periodic (0) to $(2.5)$ by $2.5 \mathrm{~N}=144$ pts: grid; Latitude $Y$ (degree_north) ordered $(90 \mathrm{~N})$ to $(90 \mathrm{~S})$ by $2.5 \mathrm{~N}=$ 73 pts: grid, with resolution $2.5^{\circ} * 2.5^{\circ}$, Singh and Ranade [8].

The MSLP dataset is also taken from NOAA NCEPNCAR CDAS-1 and covers 1979-2013. It is a gridded dataset with resolution $2.5^{\circ} * 2.5^{\circ}$, having Longitude $X$ (degree_east) periodic (0) to $(2.5)$ by $2.5 \mathrm{~N}=144$ pts: grid; Latitude $Y$ (degree_north) ordered $(90 \mathrm{~N})$ to $(90 \mathrm{~S})$ by $2.5 \mathrm{~N}=73$ pts: grid. The NCEP/NCAR Reanalysis Project is a joint project between the National Centers for Environment Prediction and the National Center for Atmospheric Research. The reanalysis output provides a potentially useful dataset for understanding the interdecadal variability in the atmosphere, Singh and Ranade [8]. The reference site for data is as follows: http://iridl.ldeo.columbia.edu/SOURCES/.NOAA/.NCEP-

NCAR/.dataset_documentation.html. 

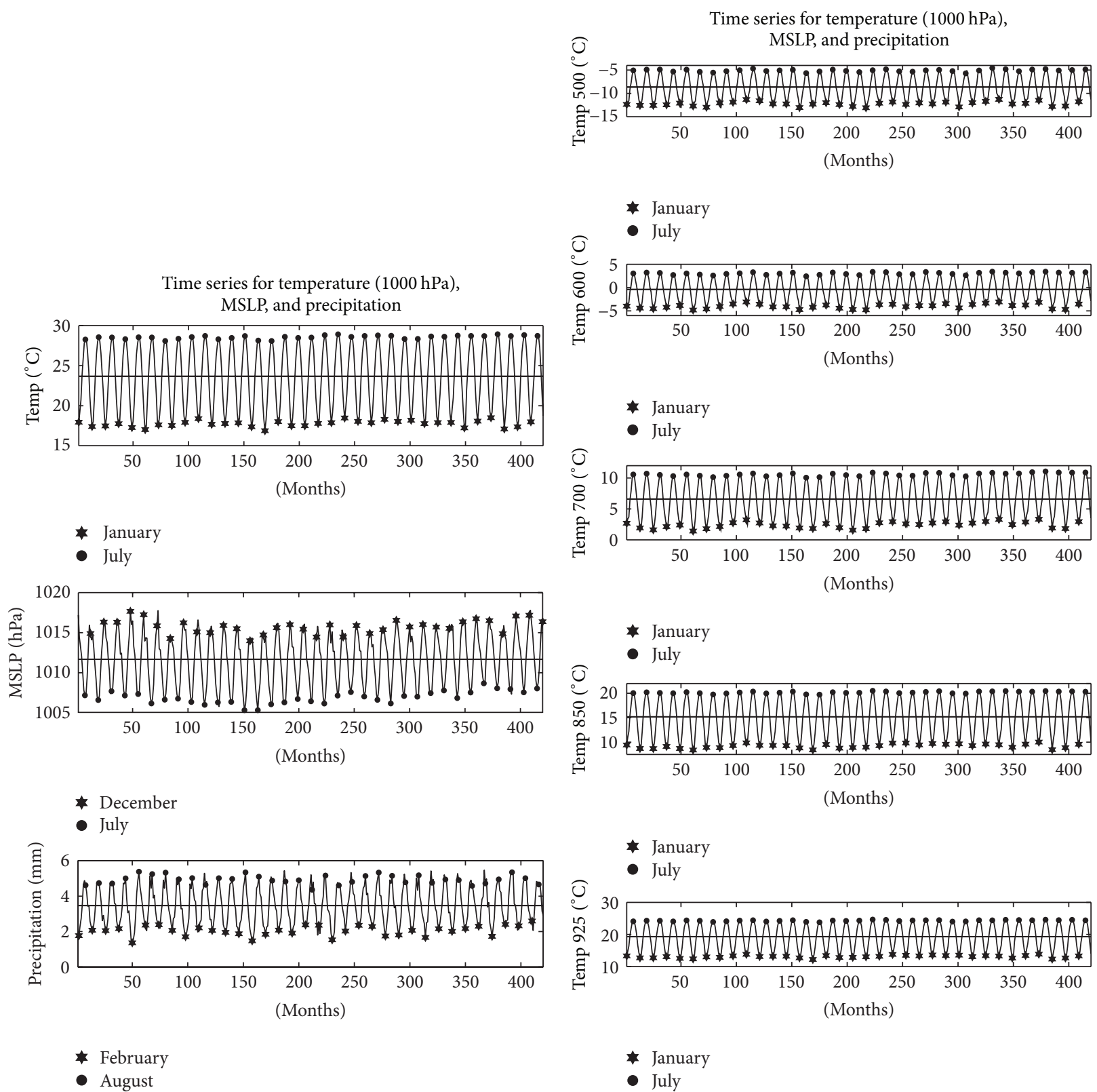

(a)

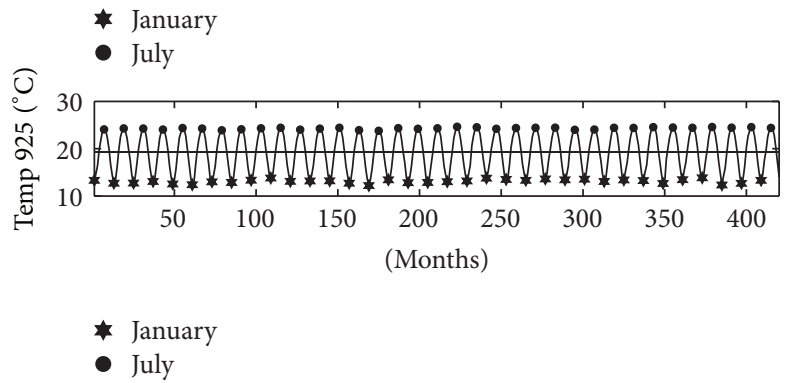

(b)

Figure 1: Times series plot for air temperature $(1000 \mathrm{hPa}-500 \mathrm{hPa})$, MSLP, and precipitation.

The study area is Asia-Pacific region (Eq. $-45^{\circ} \mathrm{N}$; $40-$ $170^{\circ} \mathrm{E}$ ), as referred in Singh and Ranade [8], for the years 1979-2013. The climatology, termed as the monthly averages, is prepared for the temperature, MSLP, and precipitation of the defined region. The next step is to calculate the anomalies. For this, the month's average is subtracted from each monthly data point and the remaining values are termed as "anomaly." Anomalies allow us to get more accurate descriptions over large areas than the actual temperature. It also sets a criterion in relation to which easier interpretation can be done. In the case of temperature anomaly, a positive anomaly means that the temperature was warmer than normal, while a negative anomaly indicates that the temperature was cooler than the normal. A positive value in precipitation indicates that the observed precipitation was greater than the average precipitation from 1979 to 2013, while a negative value indicates that the observed precipitation was less than the average precipitation from 1979 to 2013. The Monte Carlo method and the Bootstrapping method of confidence interval are used to study the correlation between the defined variables.

\section{Results and Discussion}

The result and discussion part is divided into three sections.

3.1. Time Series of Air Temperature up to the Level $500 \mathrm{hPa}$, MSLP, and Precipitation Data of Asia-Pacific Region. Figure 1 is divided into two parts as Figure $1(\mathrm{a})$, which shows the 

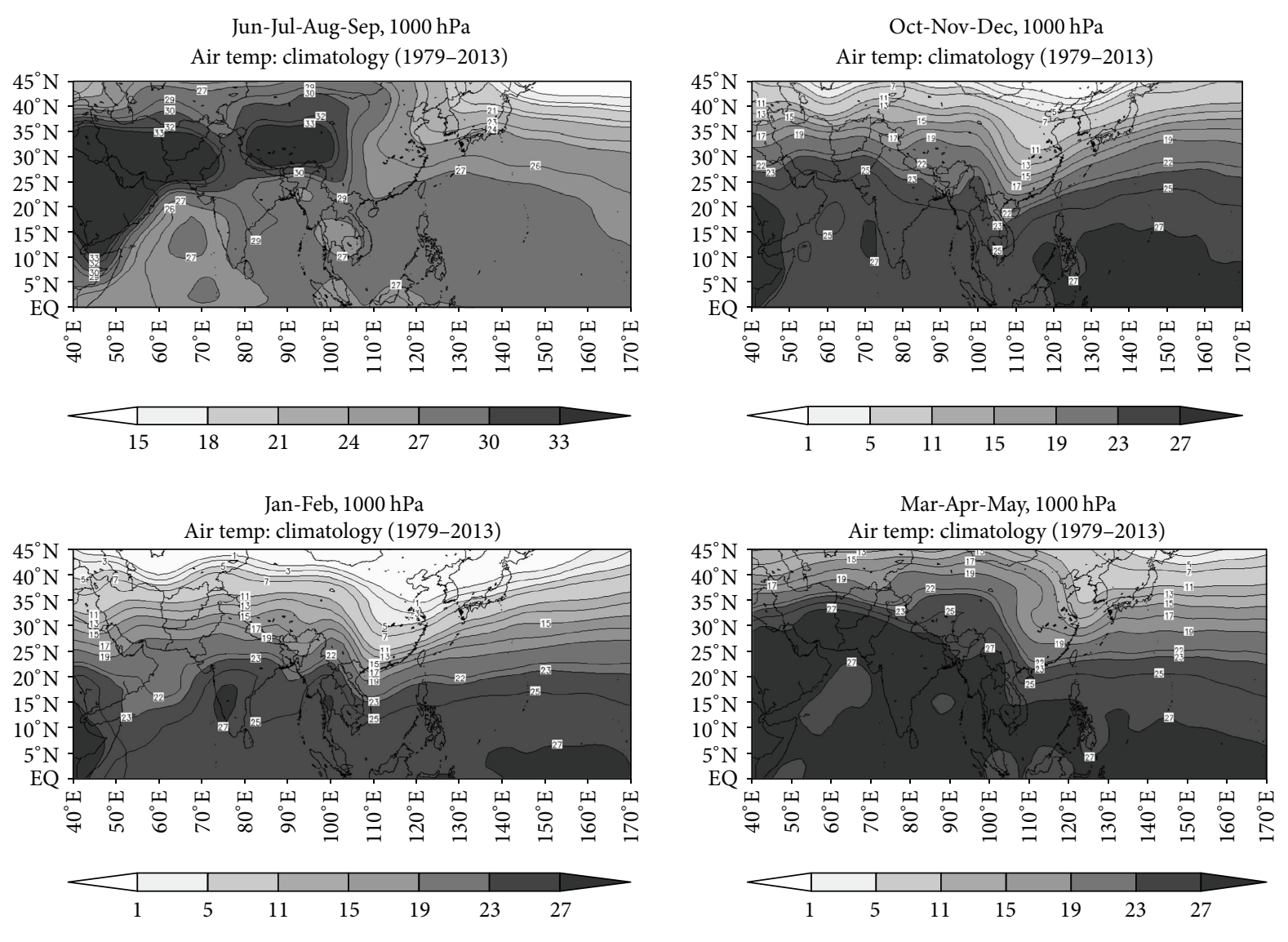

FIGURE 2: Seasonal climatology of monthly temperature at $1000 \mathrm{hPa}$.

interannual variation of temperature at $1000 \mathrm{hPa}, \mathrm{MSLP}$, and precipitation and Figure 1(b) shows the interannual variation of temperature from isobaric levels $925 \mathrm{hPa}$ to $500 \mathrm{hPa}$. The authors will try to focus on two relations: (i) temperature $(1000 \mathrm{hPa}-500 \mathrm{hPa})$ and precipitation [12] and (ii) MSLP and precipitation [15].

With respect to Figure 1(a), the mean temperature at isobaric level $1000 \mathrm{hPa}$ is around $23.6^{\circ} \mathrm{C}$. The range of temperature is from $17^{\circ} \mathrm{C}$ to $28.5^{\circ} \mathrm{C}$. The minimum temperature is observed in the month of January and the maximum temperature month is July. For MSLP the range is from $1005 \mathrm{hPa}$ to $1020 \mathrm{hPa}$. The month of July is observed as the low MSLP whereas December is observed as the high MSLP month. The mean MSLP is around $1011 \mathrm{hPa}$. In the case of precipitation, February is observed as the month of lowest average precipitation and July/August is the highest average precipitation month. A very low average precipitation of $1.3 \mathrm{~mm}$ was seen around the year 1983. During the years around 1987, 1991, 1998, 2005, and 2010, a low precipitation of $1.5 \mathrm{~mm}$ was observed.

Figure 1(b) shows the interannual variation of temperature from $925 \mathrm{hPa}$ to $500 \mathrm{hPa}$. At the isobaric level $925 \mathrm{hPa}$ the mean temperature is around $19.2^{\circ} \mathrm{C}$ and the range of temperature is from $12^{\circ} \mathrm{C}$ to $24.2^{\circ} \mathrm{C}$. The mean temperature at level $850 \mathrm{hPa}$ is about $15^{\circ} \mathrm{C}$ and the range of temperature goes from $8^{\circ} \mathrm{C}$ to $20.2^{\circ} \mathrm{C}$. For the isobaric level $700 \mathrm{hPa}$ the mean temperature is about $6.8^{\circ} \mathrm{C}$ and the range of temperature is from $1^{\circ} \mathrm{C}$ to $11^{\circ} \mathrm{C}$. At the isobaric level $600 \mathrm{hPa}$ the mean temperature is about $-0.8^{\circ} \mathrm{C}$ with the range of temperature of about $-5^{\circ} \mathrm{C}$ to $3^{\circ} \mathrm{C}$. The mean temperature at level $500 \mathrm{hPa}$ is about $-8.8^{\circ} \mathrm{C}$ and the range goes from $-13^{\circ} \mathrm{C}$ to $-5^{\circ} \mathrm{C}$. At all the respective levels $(925 \mathrm{hPa}$ to $500 \mathrm{hPa})$ the month January is observed as the minimum temperature month and July as the maximum temperature month.

3.2. Seasonal Climatology of Air Temperature at $1000 \mathrm{hPa}$, MSLP, and Precipitation. The images in Figures 2, 3, and 4 show the climatology of monthly temperature at $1000 \mathrm{hPa}, \mathrm{MSLP}$, and an average precipitation of all the four seasons June-July-August-September, October-NovemberDecember, January-February, and March-April-May, respectively.

For the season June-July-August-September, the range of temperature in the Indian monsoon region is around $24^{\circ} \mathrm{C}$ to $30^{\circ} \mathrm{C}$. The range goes from $30^{\circ} \mathrm{C}$ to $33^{\circ} \mathrm{C}$ in the East Asian region. In the Northwest Pacific region, the temperature ranges from $27^{\circ} \mathrm{C}$ to $30^{\circ} \mathrm{C}$. Taking the season October-November-December, the Indian monsoon region experiences a range of temperature of about $23^{\circ} \mathrm{C}$ to $27^{\circ} \mathrm{C}$. The East Asian region experiences a range of temperature of about $11^{\circ} \mathrm{C}$ to $23^{\circ} \mathrm{C}$. The range of temperature is about $23^{\circ} \mathrm{C}$ to $27^{\circ} \mathrm{C}$ in the Northwest Pacific region. For the season JanuaryFebruary, the range of temperature in the Indian monsoon region is about $19^{\circ} \mathrm{C}$ to $27^{\circ} \mathrm{C}$. The range goes from $5^{\circ} \mathrm{C}$ to $19^{\circ} \mathrm{C}$ 
Jun-Jul-Aug-Sep, MSLP: 1979-2013
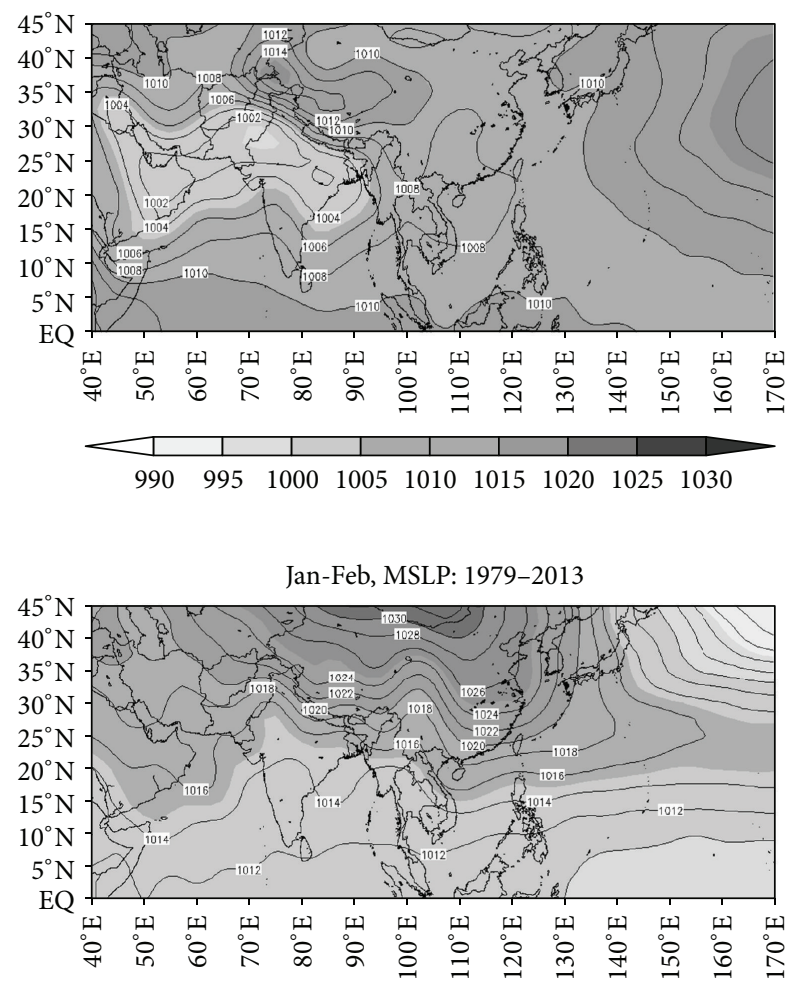

$1000 \quad 1005 \quad 1010 \quad 1015 \quad 10201025 \quad 1030 \quad 1035 \quad 1040$
Oct-Nov-Dec, MSLP: 1979-2013
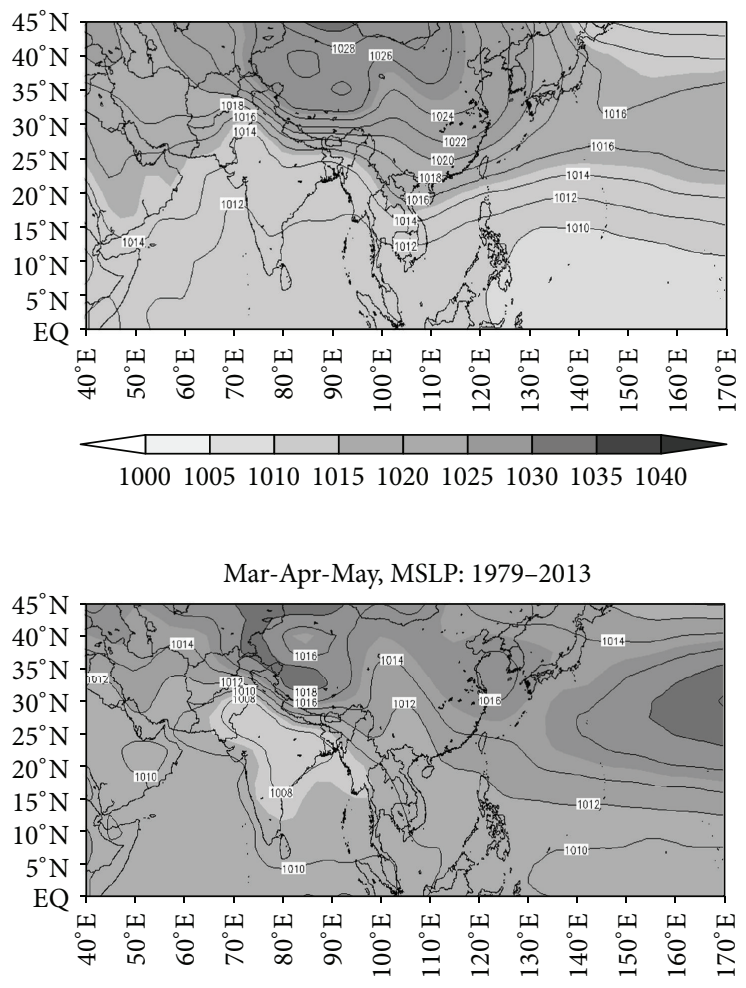

100010031006100910121015101810211024

FIgURE 3: Seasonal climatology of monthly MSLP.

in the East Asian region. In the Northwest Pacific region, the temperature ranges from $15^{\circ} \mathrm{C}$ to $27^{\circ} \mathrm{C}$. At last for the season March-April-May, the range of temperature in the Indian monsoon region is about $23^{\circ} \mathrm{C}$ to $27^{\circ} \mathrm{C}$. The range goes from $19^{\circ} \mathrm{C}$ to $27^{\circ} \mathrm{C}$ in the East Asian region. In the Northwest Pacific region, the temperature ranges from $23^{\circ} \mathrm{C}$ to $27^{\circ} \mathrm{C}$.

The range of MSLP for the season June-July-AugustSeptember in the Indian monsoon region is around $1000 \mathrm{hPa}$ to $1010 \mathrm{hPa}$. The range goes from $1005 \mathrm{hPa}$ to $1015 \mathrm{hPa}$ in the East Asian region. In the Northwest Pacific region, the MSLP ranges from $1005 \mathrm{hPa}$ to $1010 \mathrm{hPa}$. By taking the season October-November-December, the Indian monsoon region experiences a range of MSLP of about $1010 \mathrm{hPa}$ to $1015 \mathrm{~Pa}$. The region East Asia experiences a range of MSLP of about $1015 \mathrm{hPa}$ to $1025 \mathrm{hPa}$. The range of MSLP is about $1010 \mathrm{hPa}$ to $1020 \mathrm{hPa}$ in the Northwest Pacific region. For the season January-February, the range of MSLP in the Indian monsoon region is about $1010 \mathrm{hPa}$ to $1015 \mathrm{hPa}$. The range goes from $1015 \mathrm{hPa}$ to $1025 \mathrm{hPa}$ in the East Asian region. In the Northwest Pacific region, the MSLP ranges from $1010 \mathrm{~Pa}$ to $1025 \mathrm{~Pa}$. At last for the season March-April-May, the range of MSLP in the Indian monsoon region is about 1006 to $1012 \mathrm{~Pa}$. The range goes from $1012 \mathrm{hPa}$ to $1018 \mathrm{hPa}$ in the East Asian region. In the Northwest Pacific region, the MSLP ranges from $1009 \mathrm{hPa}$ to $1012 \mathrm{hPa}$.

For the season June-July-August-September, the range of average precipitation in the Indian monsoon region is about
$4 \mathrm{~mm}$ to $7 \mathrm{~mm}$ approx. The range goes from $3 \mathrm{~mm}$ to $7 \mathrm{~mm}$ in the East Asian region. In the Northwest Pacific region, the average precipitation ranges from $5 \mathrm{~mm}$ to $7 \mathrm{~mm}$. By taking the season October-November-December the Indian monsoon region experiences a range of average precipitation of about $1 \mathrm{~mm}$ to $7 \mathrm{~mm}$. The region East Asia experiences a range of average precipitation of about $1 \mathrm{~mm}$ to $3 \mathrm{~mm}$. The range of average precipitation is about $2 \mathrm{~mm}$ to $7 \mathrm{~mm}$ approx. in the Northwest Pacific region. For the season JanuaryFebruary, the range of average precipitation in the Indian monsoon region is about $0 \mathrm{~mm}$ to $2 \mathrm{~mm}$. The range lies between $1 \mathrm{~mm}$ and $2 \mathrm{~mm}$ in the East Asian region. In the Northwest Pacific region, the average precipitation ranges from $0 \mathrm{~mm}$ to $3 \mathrm{~mm}$ approx. At last for the season MarchApril-May, the range of average precipitation in the Indian monsoon region is about $1 \mathrm{~mm}$ to $5 \mathrm{~mm}$. The range goes from $1 \mathrm{~mm}$ to $5 \mathrm{~mm}$ in the East Asian region. In the Northwest Pacific region, the average precipitation ranges from $2 \mathrm{~mm}$ to $6 \mathrm{~mm}$.

The interannual variation of temperature, MSLP, and precipitation anomalies are shown in Figure 5. For the period 1983-84, a positive anomaly in MSLP and negative anomalies in temperature and precipitation can be seen. Around the years 1987-88, precipitation shows a high dip of negative anomaly whereas MSLP and temperature show a normal dip of a negative anomaly. Most of the time, MSLP is less than normal during the years 1988 to 1996 . In the case of 
Jun-Jul-Aug-Sep, GPCP: 1979-2013

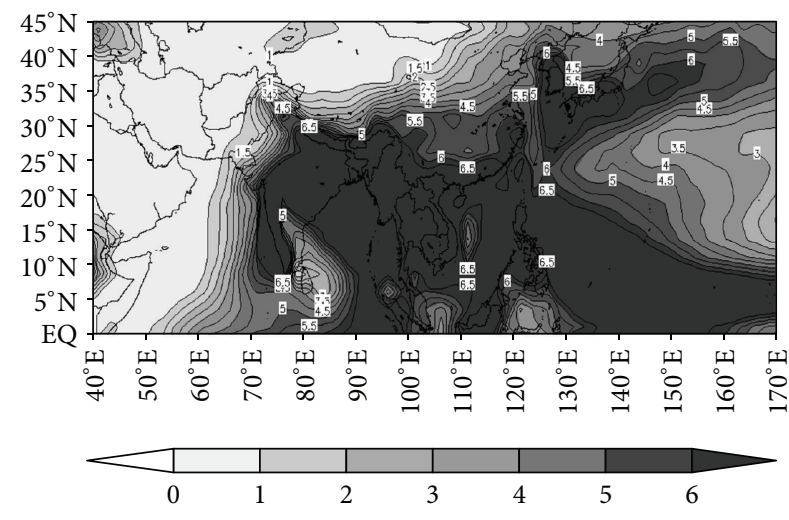

Jan-Feb, GPCP: 1979-2013
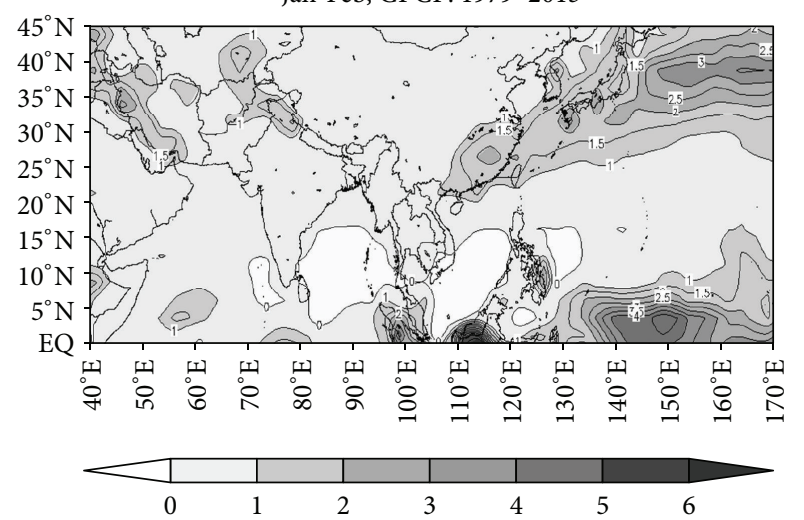

Oct-Nov-Dec, GPCP: 1979-2013
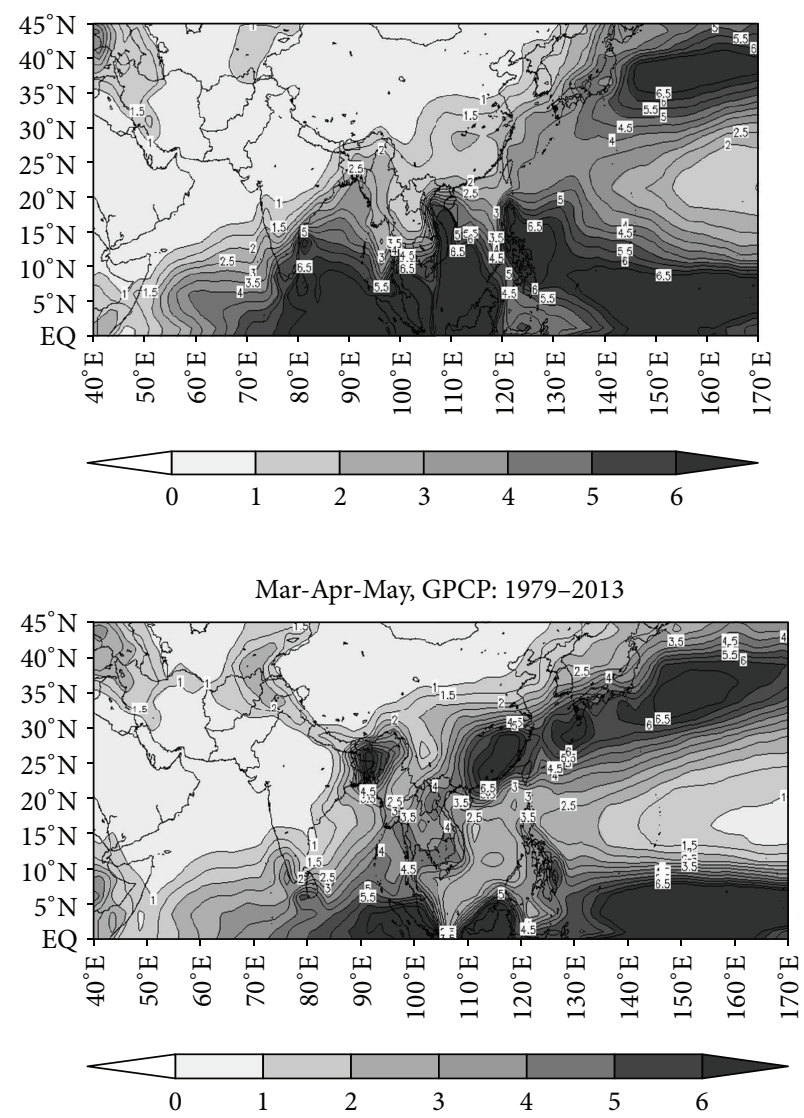

FIGURE 4: Seasonal climatology of monthly average precipitation.

rainfall, an equal positive and negative anomaly are observed during these years. The temperature shows equal positive and negative anomalies during the years 1988-92. After 199296 , a negative anomaly is seen in temperature. During the years 1997-98, a high value of positive anomaly is seen in temperature whereas MSLP and rainfall show negative values most of the time. After the year 2000, most of the time temperature is above the normal value except around 2008, 2009, and 2012. In the case of MSLP, from 2000 to 2004-06 negative anomalies are seen for nearly all the time but after that positive anomalies can be observed. Whereas rainfall shows equal positive and negative anomalies.

The interannual variation of the seasonal anomaly of temperature at $1000 \mathrm{hPa}$ is shown in Figure 6. For the seasons JJAS and OND, an increasing trend of positive anomaly is seen after 1994-95. A positive anomaly for season JF is observed after 1997-98 except around 2008 and 2012 where a negative anomaly can be seen. The positive anomaly is also observed for the season MAM also except for the year 2011. Also, an increasing trend can be seen in all the four seasons. Around the year 1997-98, a high value of positive anomaly can be seen in all the four seasons. The season JF shows a high value of negative anomaly in the year around 1984.

The interannual variability of the seasonal anomaly of MSLP is shown in Figure 7. An increasing trend can be seen in all the seasons except JF. For the seasons JJAS, OND, and MAM positive anomaly increases showing an increasing trend. Figure 8 shows the interannual seasonal variation of precipitation. The season JJAS shows a very small variation till 2005, although it is a negative anomaly but very close to zero. But after 2010 a high value of positive anomaly can be seen. For the seasons OND, JF, and MAM variation can be seen but after 2000 there is very small variation, almost constant.

\subsection{Statistical Analysis and Relation of Precipitation Data with} Temperature (at All Defined Levels) and MSLP Data. Monte Carlo simulation can be regarded as a type of simulation which relies on repeated random sampling and statistical analysis to compute the results. This is very closely related to random experiments, experiments for which the specific results are not known in advance. The main theory behind this approach is that a randomly chosen sample tends to exhibit the same properties as the population from which it is drawn, Raychaudhuri [17]. The author describes the Monte Carlo method very easily and thoroughly. Neng et al. [18] used Monte Carlo method to study the relation between South Asian summer monsoon and all India summer monsoon. The results stated that the South Asian summer monsoon index was highly correlated with all India summer monsoon.

The authors strive to ascertain the relation between GPCP with temperature at all the defined levels and MSLP with the help of Monte Carlo simulation. This part of result also 
TABLE 1: General statistics of GPCP.

\begin{tabular}{lcccccccccc}
\hline Month & Min & Max & Mean & Std. error & Std. deviation & Variance & Skewness & $\begin{array}{c}\text { Std. error } \\
\text { (skewness) }\end{array}$ & Kurtosis & Std. error (kurtosis) \\
\hline JF & -0.69 & 0.38 & 0 & 0.042 & 0.250 & 0.063 & -0.777 & 0.398 & 0.432 & 0.778 \\
MAM & -0.76 & 0.40 & 0 & 0.044 & 0.261 & 0.068 & -1.402 & 0.398 & 1.774 & 0.778 \\
JJAS & -0.17 & 0.49 & 0 & 0.023 & 0.136 & 0.019 & 1.639 & 0.398 & 3.837 & 0.778 \\
OND & -0.40 & 0.29 & 0 & 0.02 & 0.171 & 0.029 & -0.597 & 0.398 & -0.221 & 0.778 \\
\hline
\end{tabular}

TABLE 2: General statistics of temperature at $1000 \mathrm{hPa}$.

\begin{tabular}{lcccccccccc}
\hline Month & Min & Max & Mean & Std. error & Std. deviation & Variance & Skewness & $\begin{array}{c}\text { Std. error } \\
\text { (skewness) }\end{array}$ & Kurtosis & Std. error (kurtosis) \\
\hline JF & -0.97 & 0.90 & 0 & 0.077 & 0.460 & 0.211 & 0.025 & 0.398 & -0.675 & 0.778 \\
MAM & -0.59 & 0.57 & 0 & 0.050 & 0.299 & 0.089 & -0.026 & 0.398 & -0.898 & 0.778 \\
JJAS & -0.43 & 0.46 & 0 & 0.036 & 0.214 & 0.046 & -0.086 & 0.398 & -0.298 & 0.778 \\
OND & -0.74 & 0.79 & 0 & 0.055 & 0.327 & 0.107 & -0.145 & 0.398 & 0.069 & 0.778 \\
\hline
\end{tabular}

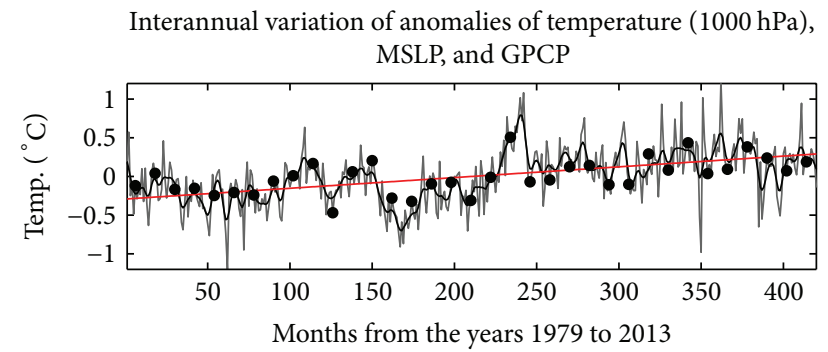

- June

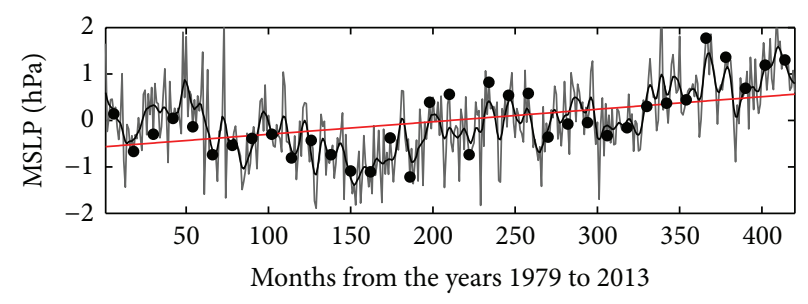

- June

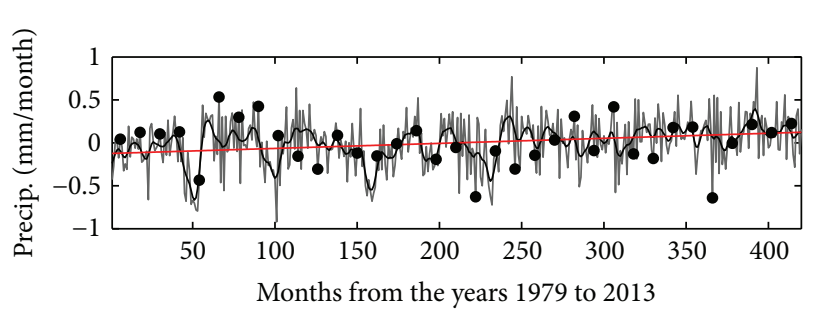

- June

FIGURE 5: Interannual variation of anomalies.

touches base with the general statistics of the anomaly data. The anomaly of GPCP, temperature, and MSLP is taken herewith to describe the relation to get perfect results. Tables 1-8 describe the general statistics of the anomaly data of GPCP, temperature, and MSLP of all the defined four seasons. The results will be used in the simulation process.
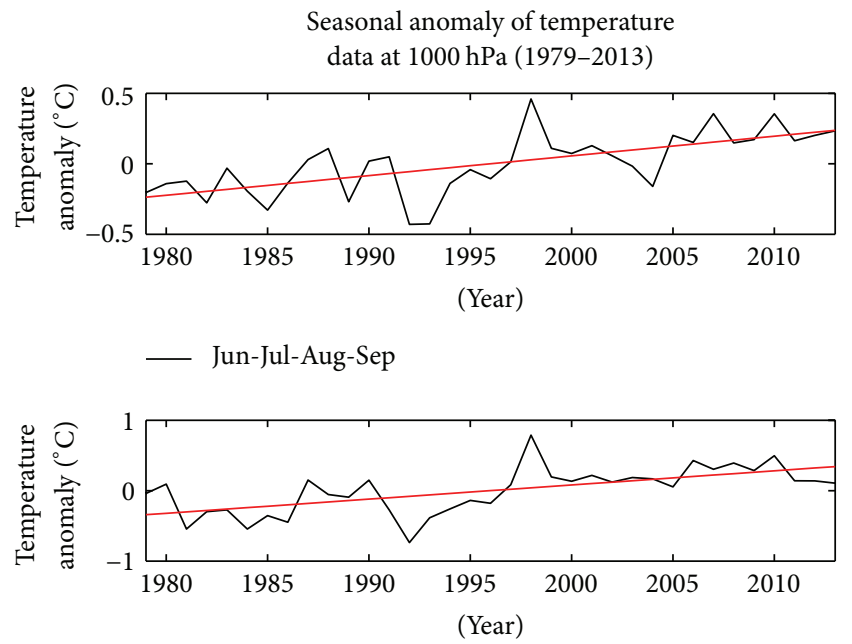

- Oct-Nov-Dec

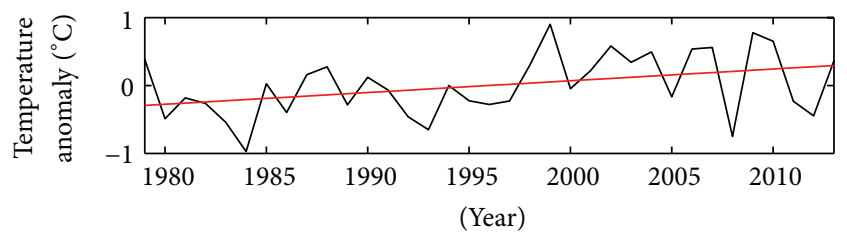

— Jan-Feb

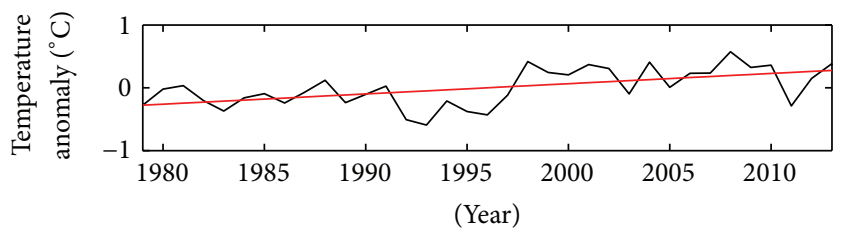

— Mar-Apr-May

FIGURE 6: Seasonal anomaly of temperature at $1000 \mathrm{hPa}$.

For the correlation of GPCP with temperature and MSLP Monte Carlo method of correlation is used. First, the distri- 
TABLE 3: General statistics of temperature at $925 \mathrm{hPa}$.

\begin{tabular}{lcccccccccc}
\hline Month & Min & Max & Mean & Std. error & Std. deviation & Variance & Skewness & $\begin{array}{c}\text { Std. error } \\
\text { (skewness) }\end{array}$ & Kurtosis & Std. error (kurtosis) \\
\hline JF & -0.99 & 0.87 & 0 & 0.082 & 0.487 & 0.238 & 0.022 & 0.398 & -0.857 & 0.778 \\
MAM & -0.66 & 0.63 & 0 & 0.054 & 0.319 & 0.102 & -0.012 & 0.398 & -0.767 & 0.778 \\
JJAS & -0.44 & 0.41 & 0 & 0.035 & 0.210 & 0.044 & -0.105 & 0.398 & -0.405 & 0.778 \\
OND & -0.79 & 0.81 & 0 & 0.058 & 0.344 & 0.119 & -0.100 & 0.398 & -0.030 & 0.778 \\
\hline
\end{tabular}

TABLE 4: General statistics of temperature at $850 \mathrm{hPa}$.

\begin{tabular}{lccccccccccc}
\hline Month & Min & Max & Mean & Std. error & Std. deviation & Variance & Skewness & $\begin{array}{c}\text { Std. error } \\
\text { (skewness) }\end{array}$ & Kurtosis & Std. error (kurtosis) \\
\hline JF & -1.11 & 0.95 & 0 & 0.090 & 0.534 & 0.285 & -0.004 & 0.398 & -0.918 & 0.778 \\
MAM & -0.74 & 0.57 & 0 & 0.059 & 0.352 & 0.124 & 0.011 & 0.398 & -0.880 & 0.778 \\
JJAS & -0.47 & 0.40 & 0 & 0.037 & 0.221 & 0.049 & -0.112 & 0.398 & -0.821 & 0.778 \\
OND & -0.77 & 0.79 & 0 & 0.062 & 0.369 & 0.136 & -0.076 & 0.398 & -0.429 & 0.778 \\
\hline
\end{tabular}
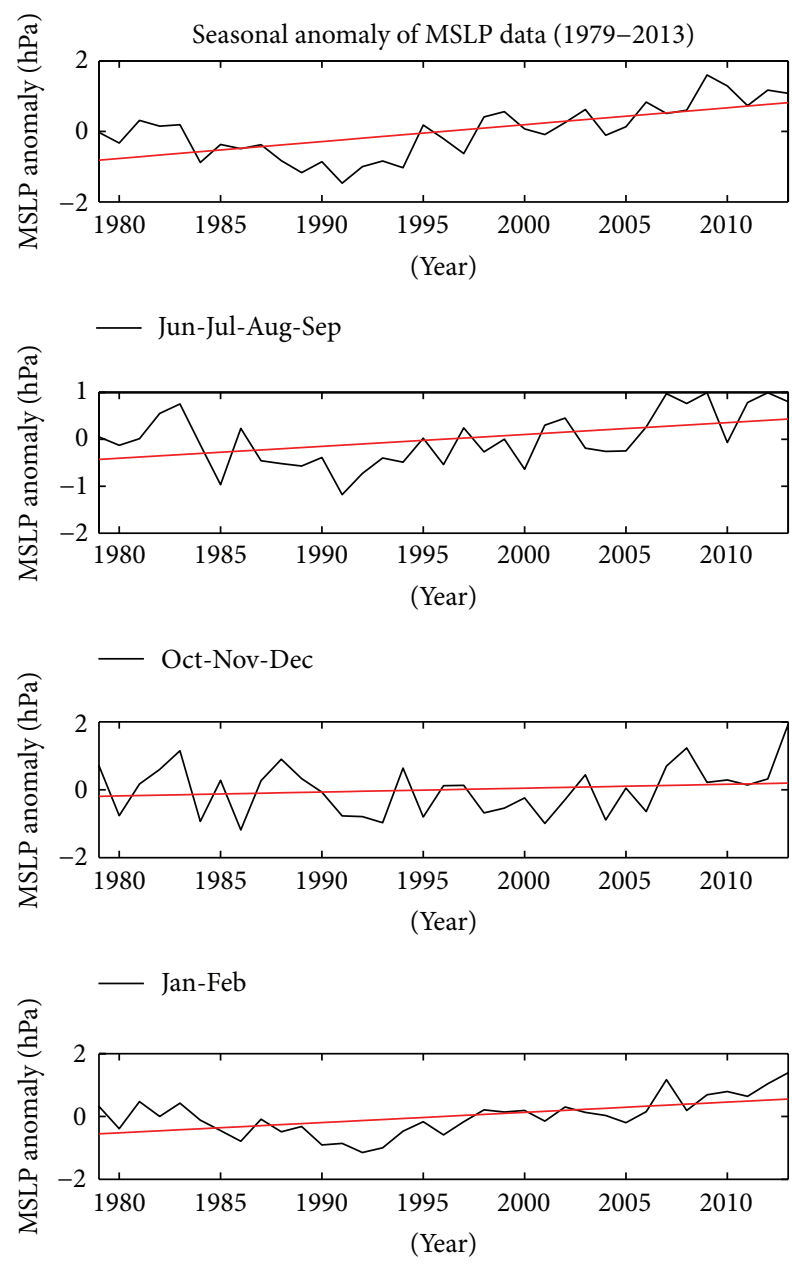

Mar-Apr-May
FIGURE 7: Seasonal anomaly of MSLP.

bution of data was identified and it was found that normal distribution happened to be the best fit to our data. The
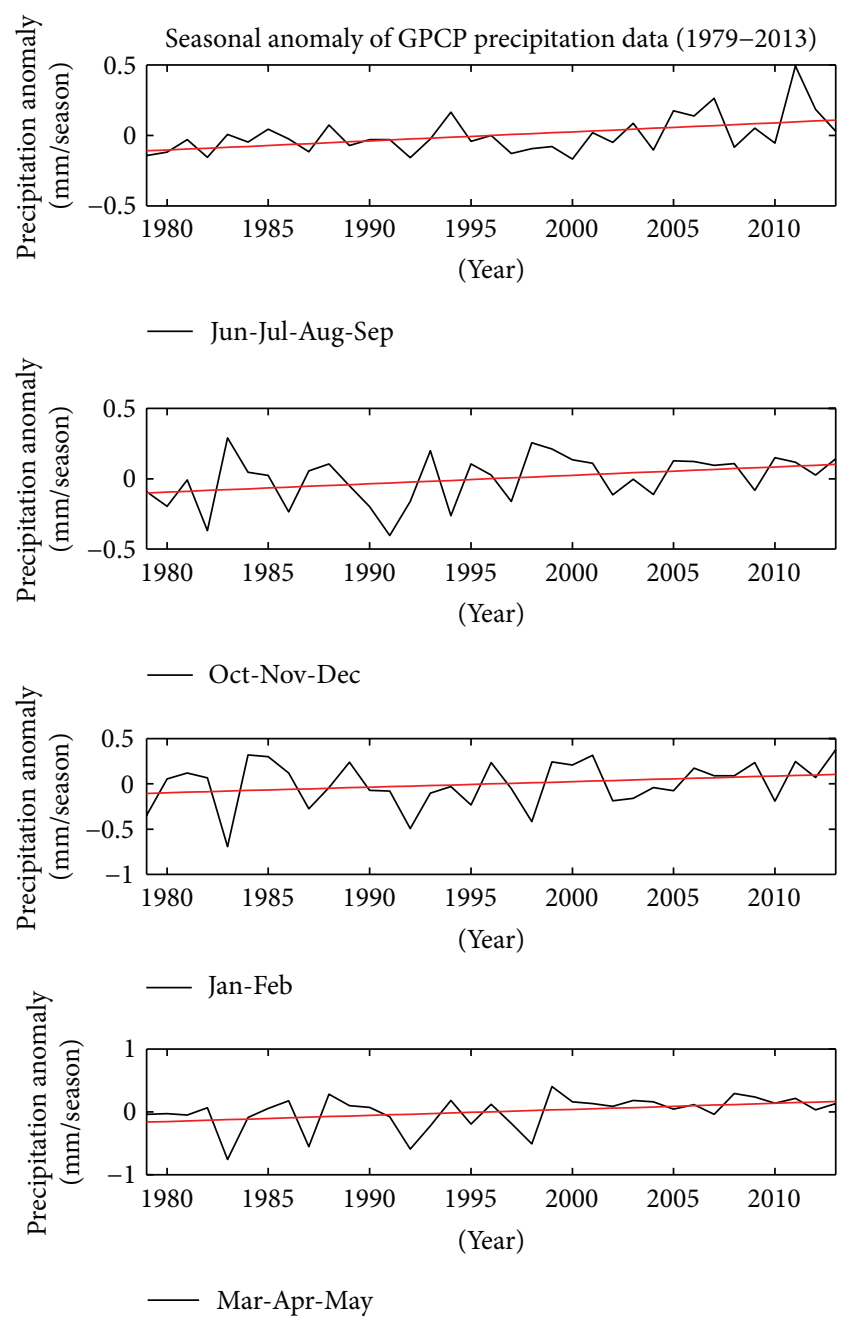

FIGURE 8: Seasonal anomaly of GPCP.

random numbers were generated of normal distribution with the help of mean and standard deviation of our data, with 
TABLE 5: General statistics of temperature at $700 \mathrm{hPa}$.

\begin{tabular}{lcccccccccc}
\hline Month & Min & Max & Mean & Std. error & Std. deviation & Variance & Skewness & Std. error (skewness) & Kurtosis & Std. error (kurtosis) \\
\hline JF & -1.00 & 1.01 & 0 & 0.091 & 0.538 & 0.290 & 0.185 & 0.398 & -1.012 & 0.778 \\
MAM & -0.73 & 0.78 & 0 & 0.059 & 0.353 & 0.125 & 0.137 & 0.398 & -0.184 & 0.778 \\
JJAS & -0.49 & 0.41 & 0 & 0.038 & 0.230 & 0.053 & -0.171 & 0.398 & -0.696 & 0.778 \\
OND & -0.51 & 0.77 & 0 & 0.054 & 0.321 & 0.103 & 0.361 & 0.398 & -0.585 & 0.778 \\
\hline
\end{tabular}

TABLE 6: General statistics of temperature at $600 \mathrm{hPa}$.

\begin{tabular}{lcccccccccc}
\hline Month & Min & Max & Mean & Std. error & Std. deviation & Variance & Skewness & $\begin{array}{c}\text { Std. error } \\
\text { (skewness) }\end{array}$ & Kurtosis & Std. error (kurtosis) \\
\hline JF & -0.75 & 0.92 & 0 & 0.080 & 0.479 & 0.229 & 0.224 & 0.398 & -1.068 & 0.778 \\
MAM & -0.66 & 0.83 & 0 & 0.059 & 0.350 & 0.123 & 0.342 & 0.398 & 0.197 & 0.778 \\
JJAS & -0.45 & 0.35 & 0 & 0.036 & 0.215 & 0.047 & -0.226 & 0.398 & -0.794 & 0.778 \\
OND & -0.48 & 0.60 & 0 & 0.049 & 0.294 & 0.087 & 0.244 & 0.398 & -0.837 & 0.778 \\
\hline
\end{tabular}

TABLE 7: General statistics of temperature at $500 \mathrm{hPa}$.

\begin{tabular}{lcccccccccc}
\hline Month & Min & Max & Mean & Std. error & Std. deviation & Variance & Skewness & $\begin{array}{c}\text { Std. error } \\
\text { (skewness) }\end{array}$ & Kurtosis & Std. error (kurtosis) \\
\hline JF & -0.78 & 0.74 & 0 & 0.067 & 0.398 & 0.159 & 0.177 & 0.398 & -0.921 & 0.778 \\
MAM & -0.71 & 0.85 & 0 & 0.057 & 0.338 & 0.115 & 0.257 & 0.398 & 0.363 & 0.778 \\
JJAS & -0.35 & 0.36 & 0 & 0.037 & 0.222 & 0.050 & -0.044 & 0.398 & -1.438 & 0.778 \\
OND & -0.55 & 0.69 & 0 & 0.047 & 0.280 & 0.079 & 0.246 & 0.398 & -0.051 & 0.778 \\
\hline
\end{tabular}

TABLE 8: General statistics of MSLP.

\begin{tabular}{lcccccccccc}
\hline Month & Min & Max & Mean & Std. error & Std. deviation & Variance & Skewness & $\begin{array}{c}\text { Std. error } \\
\text { (skewness) }\end{array}$ & Kurtosis & Std. error (kurtosis) \\
\hline JF & -1.19 & 1.93 & 0 & 0.125 & 0.740 & 0.549 & 0.377 & 0.398 & -0.169 & 0.778 \\
MAM & -1.15 & 1.39 & 0 & 0.102 & 0.608 & 0.370 & 0.250 & 0.398 & -0.121 & 0.778 \\
JJAS & -1.47 & 1.60 & 0 & 0.127 & 0.753 & 0.568 & 0.088 & 0.398 & -0.587 & 0.778 \\
OND & -1.18 & 0.99 & 0 & 0.097 & 0.574 & 0.331 & 0.159 & 0.398 & -0.692 & 0.778 \\
\hline
\end{tabular}

TABLE 9: Correlation of GPCP with temperature and MSLP, by Monte Carlo method.

\begin{tabular}{lcccc}
\hline & Jan-Feb & Mar-Apr-May & Jun-Jul-Aug-Sep & Oct-Nov-Dec \\
\hline Temp_1000 & 0.157 & 0.340 & 0.452 & 0.408 \\
Temp_925 & 0.180 & 0.383 & 0.395 & 0.382 \\
Temp_850 & 0.090 & 0.388 & 0.483 & 0.406 \\
Temp_700 & 0.076 & 0.242 & 0.495 & 0.464 \\
Temp_600 & 0.201 & 0.202 & 0.602 & 0.355 \\
Temp_500 & 0.217 & 0.300 & 0.664 & 0.480 \\
MSLP & -0.100 & 0.133 & 0.271 & 0.204 \\
\hline
\end{tabular}

reference to Raychaudhuri [17]. Hence, the simulation was performed with the help of MATLab to obtain the correlation results. Table 9 shows the correlation results of GPCP with temperature and MSLP at all the defined seasons.

A confidence interval was set up for the data and it was estimated by the method known as Bootstrapping. It is often assumed to make more sense than testing a null hypothesis,
Wood [19]. Also, the method Bootstrap confidence interval has a number of advantages over conventional methods which are thoroughly explained in Wood [19].

The method used here to generate the confidence limits is the "percentile method." First, a large number of bootstrap samples, say of size $\mathrm{n}$, are computed with replacement from a population consisting of the original data. The samples are 
TABLE 10: Actual correlation and Bootstrapping results of correlation at 95\% confidence intervals.

\begin{tabular}{|c|c|c|c|c|}
\hline & Jan-Feb & Mar-Apr-May & Jun-Jul-Aug-Sep & Oct-Nov-Dec \\
\hline Temp_1000 & $0.041[-0.3430 .364]$ & $0.401[0.0210 .671]$ & $0.372\left[\begin{array}{lll}0.080 & 0.626\end{array}\right]$ & $0.380\left[\begin{array}{lll}0.076 & 0.630\end{array}\right]$ \\
\hline Temp_925 & $0.063\left[\begin{array}{lll}-0.322 & 0.387\end{array}\right]$ & $0.377\left[\begin{array}{lll}0.004 & 0.666\end{array}\right]$ & $0.430\left[\begin{array}{lll}0.147 & 0.675\end{array}\right]$ & $0.369\left[\begin{array}{lll}0.060 & 0.615\end{array}\right]$ \\
\hline Temp_850 & $0.062\left[\begin{array}{lll}-0.303 & 0.383\end{array}\right]$ & $0.389\left[\begin{array}{lll}0.029 & 0.660\end{array}\right]$ & $0.463\left[\begin{array}{lll}0.191 & 0.688\end{array}\right]$ & $0.365\left[\begin{array}{lll}0.069 & 0.610\end{array}\right]$ \\
\hline Temp_700 & $0.013\left[\begin{array}{lll}-0.345 & 0.329\end{array}\right]$ & $0.192\left[\begin{array}{ll}-0.176 & 0.535\end{array}\right]$ & $0.455\left[\begin{array}{lll}0.186 & 0.656\end{array}\right]$ & $0.409\left[\begin{array}{ll}0.128 & 0.645\end{array}\right]$ \\
\hline Temp_600 & $0.088\left[\begin{array}{lll}-0.278 & 0.398\end{array}\right]$ & $0.076\left[\begin{array}{ll}-0.268 & 0.422\end{array}\right]$ & $0.425[0.1820 .631]$ & $0.389\left[\begin{array}{lll}0.104 & 0.619\end{array}\right]$ \\
\hline Temp_500 & $0.210\left[\begin{array}{lll}-0.278 & 0.398\end{array}\right]$ & $0.104\left[\begin{array}{ll}-0.268 & 0.422\end{array}\right]$ & $0.422\left[\begin{array}{lll}0.182 & 0.631\end{array}\right]$ & $0.442\left[\begin{array}{lll}0.104 & 0.619\end{array}\right]$ \\
\hline MSLP & $-0.002\left[\begin{array}{lll}-0.404 & 0.400\end{array}\right]$ & $0.158\left[\begin{array}{lll}-0.150 & 0.470\end{array}\right]$ & $0.306\left[\begin{array}{lll}0.022 & 0.519\end{array}\right]$ & $0.222\left[\begin{array}{lll}-0.159 & 0.536\end{array}\right]$ \\
\hline
\end{tabular}

TABLE 11: Recent 10-year changes in temperature, MSLP, and precipitation.

\begin{tabular}{lccccc}
\hline & Annual & Jan-Feb & Mar-Apr-May & Jun-Jul-Aug-Sep & Oct-Nov-Dec \\
\hline Temp_1000 & $0.30^{*}$ & $0.25^{*}$ & $0.33^{*}$ & $0.25^{*}$ & $0.27^{*}$ \\
Temp_925 & $0.32^{*}$ & $0.28^{*}$ & $0.36^{*}$ & $0.35^{*}$ & $0.39^{*}$ \\
Temp_850 & $0.39^{*}$ & $0.42^{*}$ & $0.41^{*}$ & $0.31^{*}$ & $0.45^{*}$ \\
Temp_700 & $0.39^{*}$ & $0.59^{*}$ & $0.39^{*}$ & $0.25^{*}$ & $0.36^{*}$ \\
Temp_600 & $0.33^{*}$ & $0.51^{*}$ & $0.35^{*}$ & $0.20^{* *}$ & $0.28^{*}$ \\
Temp_500 & $0.24^{* *}$ & $0.37^{* *}$ & $0.26^{* *}$ & $0.20^{* *}$ \\
MSLP & $0.82^{*}$ & 0.47 & $0.83^{*}$ & $0.15^{*}$ & $0.70^{*}$ \\
Precipitation & $0.14^{*}$ & $0.14^{*}$ & $0.18^{*}$ & 0.10 \\
\hline
\end{tabular}

drawn pair wise in order to calculate the correlation. For the 95\% confidence limits the values falling at the 2.5 and 97.5 percentiles are considered as confidence limits. For example, if the values are set to 1000 then the confidence limits will be 25 th and 975 th values. Table 10 shows the actual correlation and the Bootstrapping confidence intervals of GPCP with temperature and MSLP.

Table 11 describes the recent ten-year change in all the defined parameters testing with Student $t$-test with $1 \%$ significance level, marked as "*," and 5\% significance level, marked as “**."

\section{Conclusion}

The minimum temperature month for the Asia-Pacific region is January and the maximum temperature month is July. A constant variation of temperature is seen for all the levels from $1000 \mathrm{hPa}$ to $500 \mathrm{hPa}$. The region experiences the highest average rainfall during the season June-July-AugustSeptember. With reference to Figures 5, 6, 7, and 8, a positive anomaly in MSLP and negative anomalies in temperature and precipitation are observed during the years 1983-84. This indicates that there was a cooling in temperature and a low rainfall. The period 1987-88 suffers from a very low precipitation, with low MSLP and cool temperature. A low MSLP is observed during the years 1988 to 1996. During the years 1997-98, a good warming is observed but a good rainfall was not observed, as monsoon circulation is said to be a thermally driven circulation system. Also, the years 1997-98 are regarded as the strongest El Nino years.

While considering the interannual variation of the seasonal anomaly of temperature at $1000 \mathrm{hPa}$, the seasons JJAS and OND show an increasing trend of positive anomaly 199495, which indicates that there was a warming condition. After
1997-98 a warming is also seen in the seasons JF and MAM. An increase in temperature is seen during the years 199798 for all the defined four seasons. In the case of MSLP, an increasing trend can be observed in all the seasons except JF. The season JJAS shows a very small variation till 2005, although it is a negative anomaly but very close to zero. But after 2010 an increase in precipitation can be observed. For the seasons OND, JF, and MAM variation can be seen but after 2000 there is very small variation, almost constant.

The GPCP is showing a very good positive correlation with temperature at levels $1000 \mathrm{hPa}, 925 \mathrm{hPa}$, and $850 \mathrm{hPa}$ for the seasons MAM, JJAS, and OND. The temperature at levels $700 \mathrm{hPa}, 600 \mathrm{hPa}$, and $500 \mathrm{hPa}$ shows a good correlation with GPCP for the seasons JJAS and OND. The season JF shows a negative weak correlation between GPCP and MSLP. Also, a weak positive correlation is seen for the seasons MAM, JJAS, and OND. With reference to Tables 9 and 10, GPCP shows a very good correlation with temperature at all the defined levels for all the seasons except JF. If we focus on the recent 10-year changes in Asia-pacific region (with reference to Table 11), the temperature has increased from its normal (median). Also, the precipitation is showing a positive value, that is, increase in precipitation but with a low rate.

Since with the limited datasets the results are seen as perfect, if more datasets and parameters of Wind are taken into consideration along with geopotential height, outgoing longwave radiation, and so forth, the result will be more accurate which will help to understand the variability of monsoon in a more improvised way. The researchers want to extrapolate the findings and the analysis report to the Indian subcontinent to review and analyze the effect on the aforesaid region which might influence the various factors and variables. 


\section{Abbreviations}

MSLP: Mean sea level pressure

JJAS: June-July-August-September

OND: October-November-December

JF: January-February

MAM: March-April-May

GPCP: Global Precipitation Climatology Project.

\section{Competing Interests}

The authors declare that they have no competing interests.

\section{Acknowledgments}

The authors thank IRI Data Library which is a powerful and freely accessible online data repository and helps the user to view, download, and analyze the reanalysis climate data. They would also like to thank the Department of Physics and the Department of Civil and Environmental and Engineering, BIT, Mesra, Ranchi, for this cooperation. They also thank Dr. Ashwini Ranade for her guidance and support.

\section{References}

[1] Q. Weihong and Y. Zhu, "The comparison between summer monsoon components over East Asia and South Asia," Journal of Geosciences of China, vol. 4, no. 3-4, pp. 17-32, 2002.

[2] B. Wang, R. Wu, and K.-M. Lau, "Interannual variability of the asian summer monsoon: contrasts between the Indian and the Western North Pacific-East Asian monsoons," Journal of Climate, vol. 14, no. 20, pp. 4073-4090, 2001.

[3] G. Choi, D. Collins, G. Ren et al., "Changes in means and extreme events of temperature and precipitation in the AsiaPacific Network region, 1955-2007," International Journal of Climatology, vol. 29, no. 13, pp. 1906-1925, 2009.

[4] P. Zhao, J. Chen, D. Xiao, S. Nan, Y. Zou, and B. Zhou, "Summer Asian-Pacific oscillation and its relationship with atmospheric circulation and monsoon rainfall," Acta Meteorologica Sinica, vol. 22, no. 4, pp. 455-471, 2008.

[5] J. Li, Y. Zheng, F. Li, F. Guo, and W. Li, “The structural characteristics of precipitation in Asian-Pacific's three monsoon regions measured by tropical rainfall measurement mission," Acta Oceanologica Sinica, vol. 33, no. 3, pp. 111-117, 2014.

[6] B. N. Goswami, South Asian Monsoon, Intraseasonal Variability in the Atmosphere-Ocean Climate System, Springer, Berlin, Germany, 2nd edition, 2012.

[7] L. Ka-Ming and M.-T. Li, "The monsoon of east asia and its global associations-a survey," Bulletin of the American Meteorological Society, vol. 65, no. 2, pp. 114-125, 1984.

[8] N. Singh and A. A. Ranade, "Determination of onset and withdrawal dates of summer monsoon across India using NCEP/ NCAR re-analysis," Research Report RR-124, Contribution from IITM, 2010.

[9] R. S. Maragatham, "Trend analysis of rainfall data-a comparative study of existing methods," International Journal of Physics and Mathematical Sciences, vol. 2, no. 1, pp. 13-18, 2011.

[10] P. Berg, J. O. Haerter, P. Thejll, C. Piani, S. Hagemann, and J. H. Christensen, "Seasonal characteristics of the relationship between daily precipitation intensity and surface temperature,"
Journal of Geophysical Research Atmospheres, vol. 114, no. 18, Article ID D18102, 2009.

[11] C. Yao, S. Yang, W. Qian, Z. Lin, and M. Wen, "Regional summer precipitation events in Asia and their changes in the past decades," Journal of Geophysical Research: Atmospheres, vol. 113, no. 17, Article ID D17107, 2008.

[12] K. E. Trenberth and D. J. Shea, "Relationships between precipitation and surface temperature," Geophysical Research Letters, vol. 32, no. 14, Article ID L14703, 2005.

[13] R. Benzi, R. Deidda, and M. Marrocu, "Characterization of temperature and precipitation fields over sardinia with principal component analysis and singular spectrum analysis," International Journal of Climatology, vol. 17, no. 11, pp. 1231-1262, 1997.

[14] T. J. Ansell, C. J. C. Reason, I. N. Smith, and K. Keay, "Evidence for decadal variability in southern Australian rainfall and relationships with regional pressure and sea surface temperature," International Journal of Climatology, vol. 20, no. 10, pp. 1113$1129,2000$.

[15] D. Lavers, C. Prudhomme, and D. M. Hannah, "European precipitation connections with large-scale mean sea-level pressure (MSLP) fields," Hydrological Sciences Journal, vol. 58, no. 2, pp. 310-327, 2013.

[16] R. F. Adler, G. J. Huffman, A. Chang et al., “The version-2 global precipitation climatology project (GPCP) monthly precipitation analysis (1979-present)," Journal of Hydrometeorology, vol. 4, no. 6, pp. 1147-1167, 2003.

[17] S. Raychaudhuri, "Introduction to monte carlo simulation," in Proceedings of the 2008 Winter Simulation Conference (WSC '08), S. J. Mason, R. R. Hill, L. Mönch, O. Rose, T. Jefferson, and J. W. Fowler, Eds., pp. 91-100, Miami, Fla, USA, December 2008.

[18] S. Neng, G. Jun-Qiang, Y. Yan-Ming, and L. Zhen-Min, "An improved south Asian summer monsoon index with Monte Carlo test," Chinese Physics, vol. 14, no. 4, pp. 844-849, 2005.

[19] M. Wood, "Statistical inference using bootstrap confidence intervals," Significance, vol. 1, no. 4, pp. 180-182, 2004. 

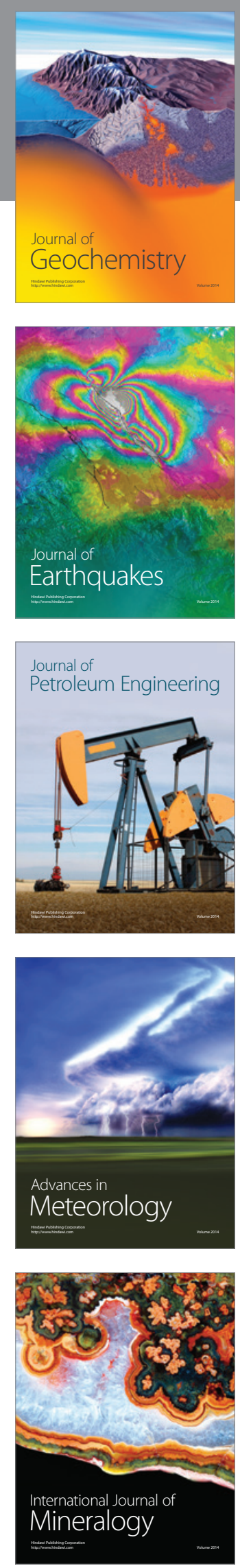
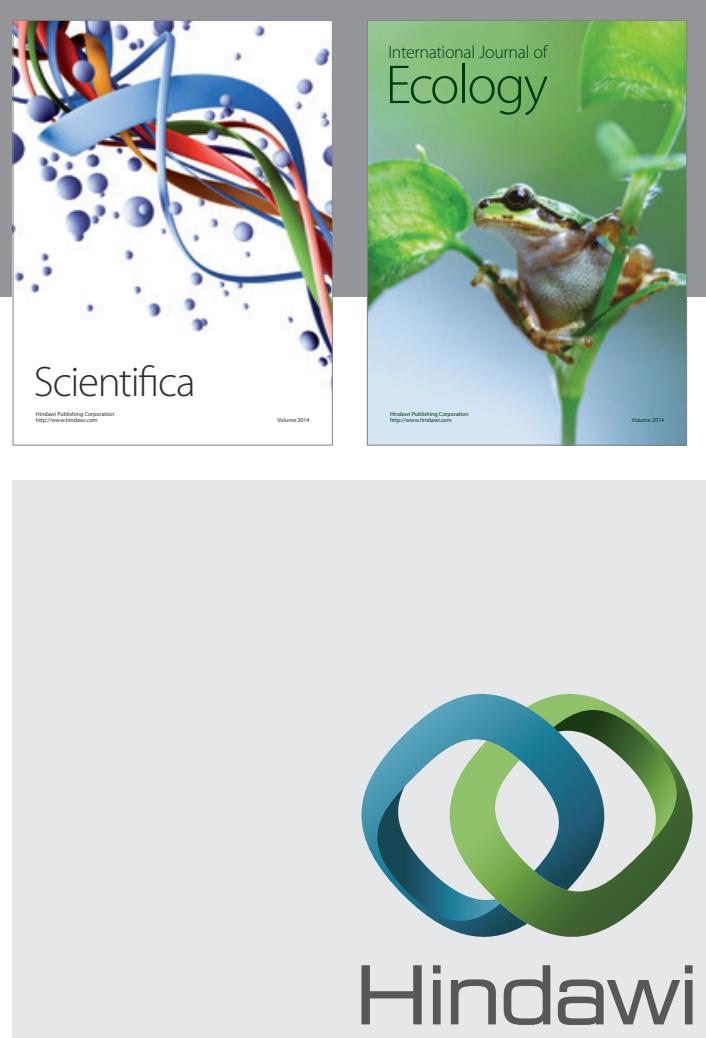

Submit your manuscripts at

http://www.hindawi.com
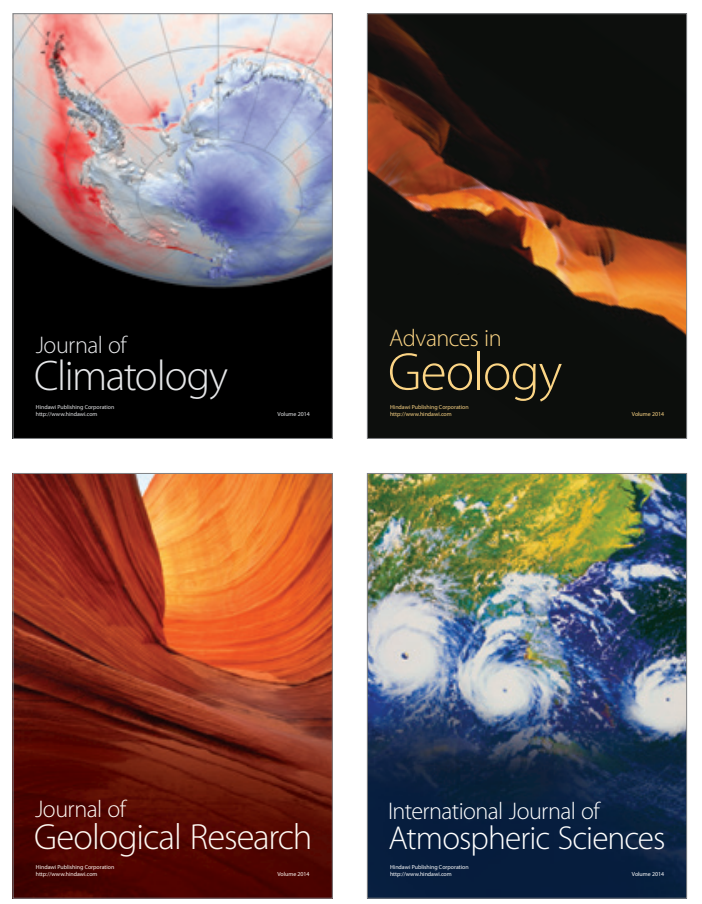

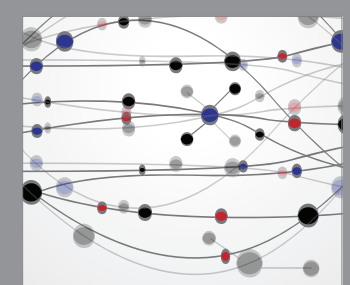

The Scientific

\section{World Journal}
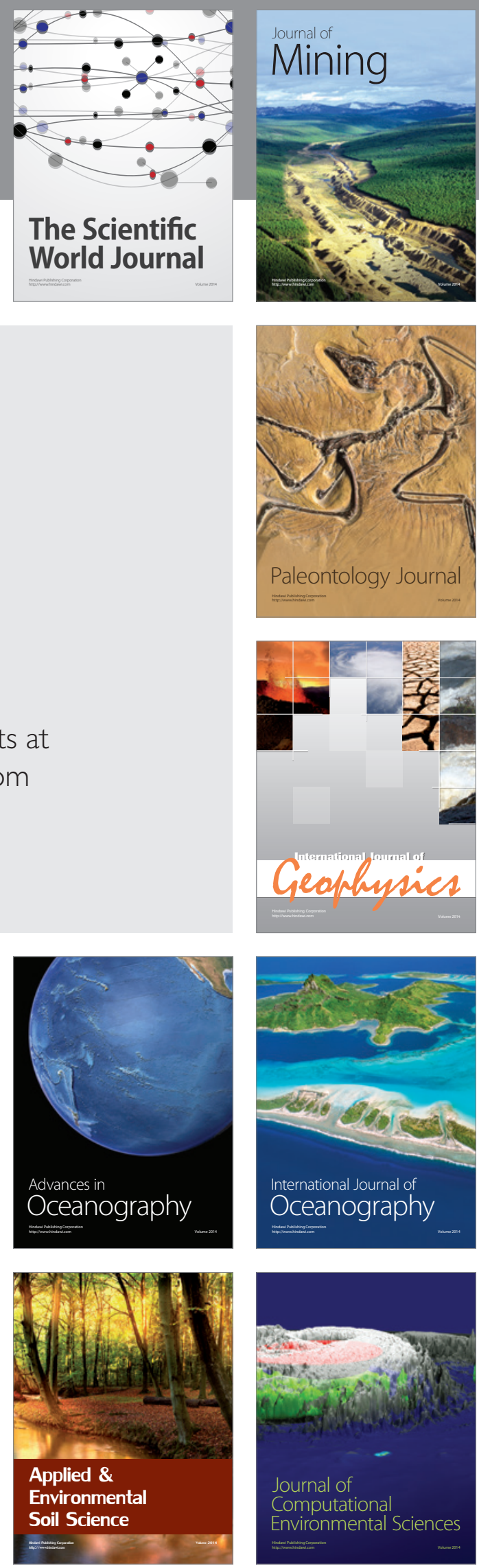